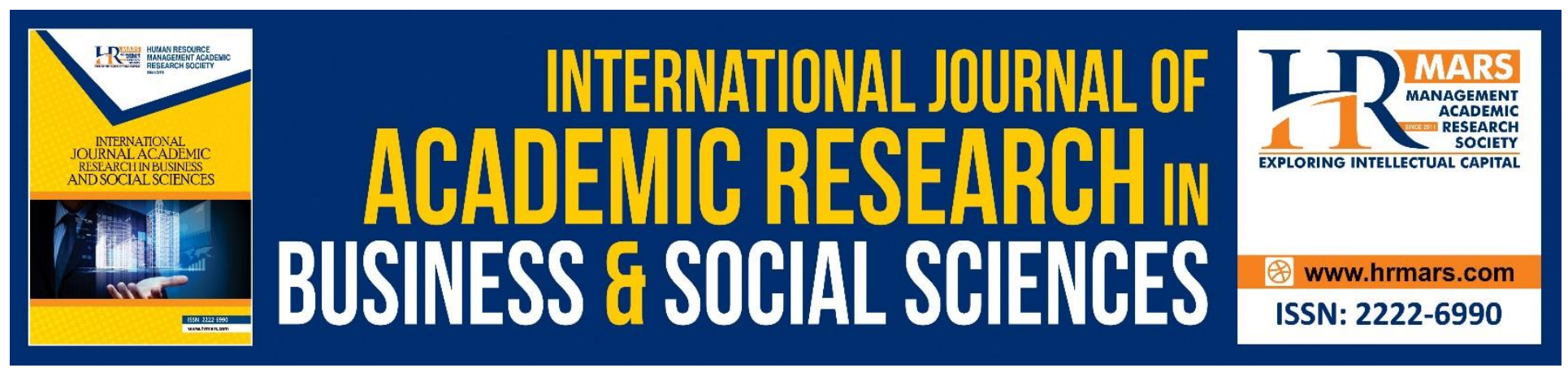

\title{
Assessment of Agro-Based Homestay Activities towards Muslim Friendly Tourism
}

Rashidi Othman, Adib Azman, Khairusy Syakirin Has-Yun Hashim, Hidayah Radin, Mashhuda Adzhar, Lukman Hakim Mahamod and Nurrulhidayah Ahmad Fadzillah

To Link this Article: http://dx.doi.org/10.6007/IJARBSS/v9-i2/5638

DOI: $\quad 10.6007 /$ IJARBSS/v9-i2/5638

Received: 12 Jan 2019, Revised: 23 Feb 2019, Accepted: 25 Feb 2019

Published Online: 10 March 2019

In-Text Citation: (Othman et al., 2019)

To Cite this Article: Othman, R., Azman, A., Hashim, K. S. H.-Y., Radin, H., Adzhar, M., Mahamod, L. H., \& Fadzillah, N. A. (2019). Assessment of Agro-Based Homestay Activities towards Muslim Friendly Tourism. International Journal of Academic Research in Business and Social Sciences, 9(2), 901-909.

Copyright: (c) 2019 The Author(s)

Published by Human Resource Management Academic Research Society (www.hrmars.com)

This article is published under the Creative Commons Attribution (CC BY 4.0) license. Anyone may reproduce, distribute, translate and create derivative works of this article (for both commercial and non-commercial purposes), subject to full attribution to the original publication and authors. The full terms of this license may be seen at: http://creativecommons.org/licences/by/4.0/legalcode

Vol. 9, No. 2, 2019, Pg. 901 - 909

http://hrmars.com/index.php/pages/detail/IJARBSS

JOURNAL HOMEPAGE

Full Terms \& Conditions of access and use can be found at http://hrmars.com/index.php/pages/detail/publication-ethics 


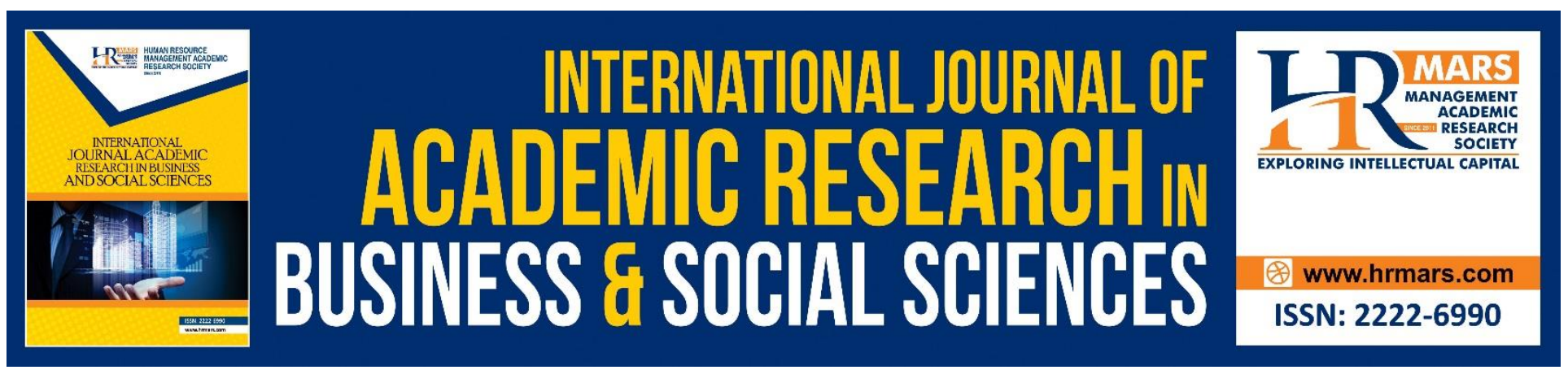

\title{
Assessment of Agro-Based Homestay Activities towards Muslim Friendly Tourism
}

\author{
Rashidi Othman, Adib Azman, Khairusy Syakirin Has-Yun Hashim, \\ Hidayah Radin, Mashhuda Adzhar, Lukman Hakim Mahamod and \\ Nurrulhidayah Ahmad Fadzillah \\ International Institute of Halal Research and Training (INHART), \\ Department of Landscape Architecture, Kulliyyah of Architecture \& Environmental Design, \\ International Islamic University Malaysia, Jalan Gombak, 53100 Kuala Lumpur, Malaysia.
}

\begin{abstract}
The homestay programme in Malaysia was first introduced in 1988 by the Ministry of Tourism as to match the demand of an emerging tourist segment and the alternatives for tourist of those who travel in the quest for the experience that enhances knowledge. Homestay can be defined as one type of lodging that the tourists share with the homeowner with the intention to learn culture and lifestyles from the homeowner. Malaysia is one of the Muslim countries in Southeast Asia that received billions of tourists all over the world. However, the provision of Muslim-friendly tourism accommodation is still lacking. Hence, the aim of this research to explore the interrelationship of agro-cultural based homestay activities, spatial organization, social interaction and landscape setting towards Islamic Built Environment. All these components need to be suitable for guests and hosts to reach the guideline abided by Islamic principles. Methods of observation throughout the house and interview conducted with the hosts are used to investigate the criteria of Shari'ah compliance applied. Based on the data analysis, the Shari'ah compliance abided by the guests and the hosts can sustain the cultural and the agro-tourism homestay that becomes their identity integrated with Islamic Built Environment from faded away. In conclusion, based on the findings of this study, the Shari'ah compliances implemented can enhance the quality of the activities, spatial organization, social interaction and the landscape setting in the homestay programme in the future.
\end{abstract}

Keywords: Agro-Based Homestay, Islamic Built Environment, Muslim Friendly Tourism

\section{Introduction}

In these days, the demand of Islamic tourism in Malaysia has been increasing rapidly. Malaysia is one of the famous destinations of Muslim tourist from the middle east. The tourism sector in Malaysia supported by local tourist and visitor due to introducing of 5 days working days. In response to that situation, particularly to the local tourist that well understand about Islamic teaching, Muslims in 
Malaysia realize Shari'ah compliant is not only for activities related to the economy, law and education, but it covers all aspects of life including hospitality and tourism industry. Hospitality in tourism industry quickly responded by introducing Shari'ah compliant hotels which provide halal food, non-alcohol bar and space for praying. The argument arising from this matter is whether others tourism accommodation premises such as homestay, compliant with Shari'ah or not come into picture when it looks not harmonies with surrounding physical environment as well as social interaction. Hence, this research aimed to explore the interrelationship of agro-based homestay activities, social interaction, space organization and landscape setting with Islamic Built Environment which combining agro-tourism and cultural tourism that usually come together in homestay programme.

Among the reasons why homestay exists in this country is because there is demanding to stay overnight and the interest to know more and experience the local culture (Amran, 1997). In the beginning, most of the pioneers' homestay located along the beach area. Then, in the late 1980s, the homestay concept made another step of dimension changes with the arrival of Japanese youth on exchange programs. Since then, the Ministry of Agriculture used homestay programmed as a catalyst for rural development (Ibrahim, 2010).

According to Boonratana (2010), homestay can be defined as a place that provides a unique opportunity for tourists, for an affordable fee, to explore and experience a simple or traditional lifestyle through close interaction and communication with the host family members, including the involvement with the host family's daily activities within a comfortable homely setting. In agreement with that, Pusiran (2013) stated that the wider definition of the homestay is by interpreting it as a commercial home whereby visitors or guest pay for a certain amount according to the package offered to stay in a private home where bring it into an interaction and communication with the host and the family members. At the same time, it shows a unique picture to the global about the concept of the homestay that promotes interaction between host's families and tourists and plays a role as a catalyst to raise an awareness on the importance of experienced a cultural exchange and learn how to respect for the host's culture.

Since 1995, the homestay programme in Malaysia has been announcing as a rural and culturalcommunity based tourism. This activity aiming to develop rural communities, to decrease the economic imbalance between rural and urban area as well as to ensure the ethnic participations of both rural and urban in tourism activities. (Othman et al., 2015). Siwar (2013) described that a traditional homestay's type offers guests in eating, cooking and other activities, exchanging and learning the different culture. The host of the homestay also will ensure the cleanliness for the comfort and safety. Other than that, there is another type of homestay which is modern and urban homestay that slightly different from the traditional-based homestay. They offer challenging vacations activities with contemporary facilities and usually there is no host involved in this type of homestay (Othman et al., 2015).

Agrotourism can be defined as an activity of vacation in the rural area that leads to the contribution of rustic improvement by providing new jobs and new value added. Besides, it also gives the possibility for the guest to come direct contact with the local community to encounter the area and to value more the local products, the services and the existing landscape setting (Sznajder et al., 2009). Intan et al., (2011) studied that agrotourism implemented in homestay programme has been 
identifying as a unique vacation product in which culture and natural heritage integrate as an exposure for tourists to gain experience towards ambiance of the village. Besides, variety and accessibility also affect tourist satisfaction. For instance, the capability of an organization has been recognizing as the most critical factor for the success of the homestay programme (Levina and Ross, 2003).

According to Omer (2015), Islam is a universal religion and as a framework of Muslim lifestyles. It is not only confining into specific ethnic, historic episode or even because of the geographical reason. It offers to all people to enrich their various style, methods and technique to enjoy its benefits. Islamic environment is a global phenomenon that interprets the idea of the world. It also a product of an interplay between the absolute or permanent and the relative or temporary realities. Shari'ah compliant not only related to the economy, law and education but it also covers all aspects of life including the hospitality and tourism industry. Shari'ah in Arabic word means the path that should be followed by Muslims (Doi, 1998). Ahmad (2000), also highlighted that activities according to Shari'ah must be based on four philosophic foundations of maqasid shari'ah which are; tauhid, rububiyah, khilafah and tazkiyyah. Maqasid shari'ah is made to allow Muslims to achieve the highest state and to fulfill basic human necessities.

\section{Methodology}

On-site Observation

On-site observation is done to study the design elements, spatial organization and landscape setting of the homestay. Information is obtained through observation and case studies in existing homestay that may or may not follow shari'ah compliant regulations. The site studies located at Banghuris Homestay, Sepang, Selangor, and Sungai Sireh Homestay, Tanjung Karang, Selangor.

\section{Interviews}

The interviews were conducted with experienced individuals from design backgrounds based on the individual's design solution tactics, opinions, space planning and layout ideas.

\section{Secondary Data}

Secondary data was collected through different means and sources, that are taken directly or indirectly from books, journals, reports, articles and guidelines. This method is used throughout the study period. The documents are used as preliminary study as to get an overview of the subject studied, then being used again to strengthen and complement the data acquired from interview and observation conducted.

Data Analysis

After the checklist was updated and recorded, the collected data were analyzed in details, and the results were presented accordingly. The data was analyzed based on the maqasid shari'ah principles which include three stages of human welfare namely: 1) dharuriyyah (necessity), 2) hajiyyah (needs) and 3) tahsiniyyah (complimentary).

\section{Data Analysis and Discussion}

Based on the homestays that have been selected which are Homestay Banghuris, Sepang, Selangor and Homestay Sungai Sireh, TanjungKarang, Selangor, the detailed information about the 
agro-based homestay activities, social interaction, spatial organization and landscape setting with Islamic Built Environment are as follows:
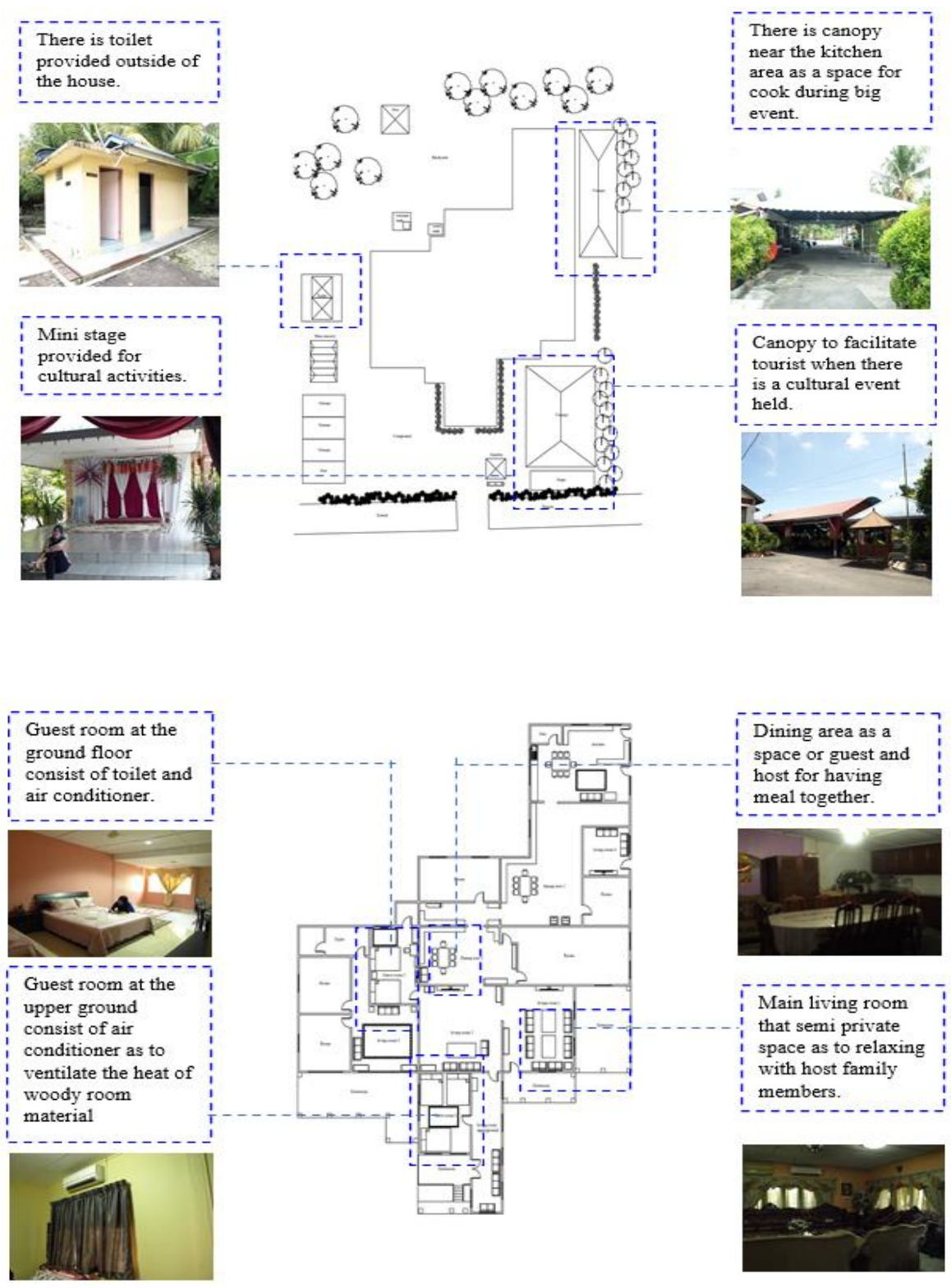

Figure 1. The outdoor and indoor layout of Banghuris Homestay 

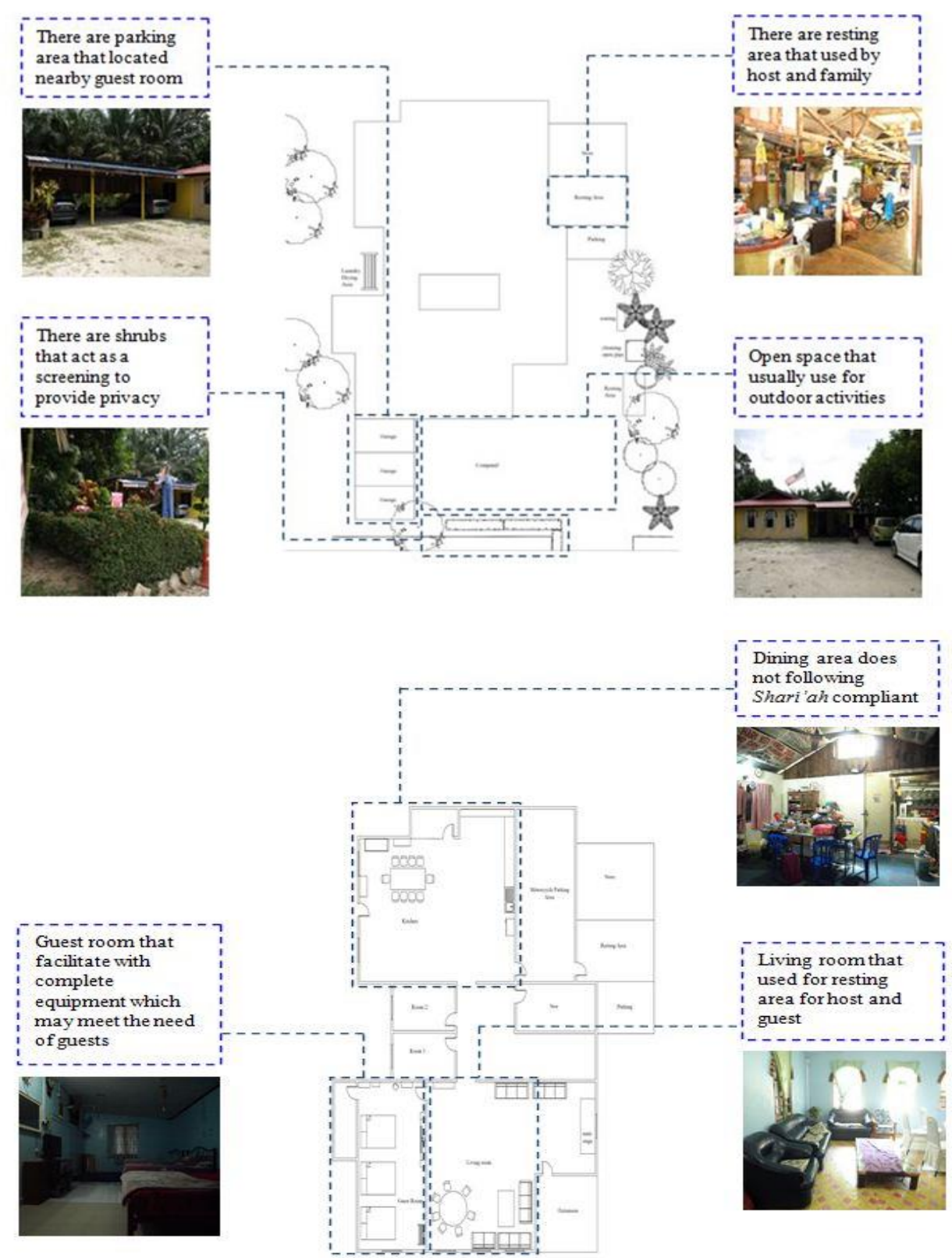

Figure 2. The outdoor and indoor layout of Sungai Sireh Homestay

The plan in Figure 1 indicated that the components and accommodations provided in the Homestay Banghuris indoor area were divided into two level which is ground floor and upper ground. There is one guest room on the ground floor and one more on the top floor of the house. The necessities that need to be installed in a room was well applied in the guest room on the ground 
floor. For example, two queen size beds, comforters, mirror, cabinet and wardrobe same with the guest rooms on the upper ground. These two guest rooms can allocate around 5 people at one time. The toilet inside the guest rooms on the ground floor guarantees the privacy of the guests. However, the guest room at the upper level causing the guests to use the toilet at the ground level that might cause privacy disturbance. It might be one of the difficulties for the guest accessibility in the house in term of their aurah privacy between hosts and the guests. The arrangement and placement of the furniture in both rooms are following the guideline in shari'ah compliant by fulfilling the needs of the Muslim guests. The utmost priority is both guest rooms provide space for guests to perform their daily five prayers. The prayer mat, telekung and kain pelikat provided by the host. As for the interior decoration of the room and the house, they still following the shari'ah by not depict the human form, reflected the humbleness and modest lifestyle of the host. The living rooms existing in this house are all easy to access from one space to another space and not interrupt the social interaction in the house. The size of living rooms is enough to gather the guests with the host and family members as to strengthen the bond together and it is comfortable with the installation of an air conditioner as the air ventilation for the house. The dining area allocates enough space for the guest to enjoy their meals together with the host. The prime highlight is the owner of the house is stressing about the cleanliness as in Islam purification is vital to avoiding the wastage as to ensure the guest are not in harm.

Figure 2 showed the indoor plan for Sungai Sireh Homestay and its surrounding compound consists of bushes and oil plantation farm. At the main entrance, there was a shrub that acts as a screening to ensure the open space can be used by the host privately. There is also an open space at the center that used for outdoor activities such as hangout, chatting and many more. The host provides garage that consists of three car parking lots with dimension $5 \mathrm{~m}$ by $7.5 \mathrm{~m}$. The garage is located nearby the guest room that allowed the visitors from outside to see the guest directly from inside. At the left side of the house, there was also a resting area that usually used by the host and family members to have tea time and some discussion. The arrangement was quite informal but comfortable to stay for any purpose. This homestay has three rooms and only one room meant for the guest. The capacity of the guest room can be occupied from 6 to 10 persons. The guest room was facilitated with television, refrigerator, air-conditioner and toilet. The host complied with Shari'ah needs by giving kiblah direction and praying kit such as praying mat and telekung (prayer vale). Concerning accessibility, it easy to access from the main entrance to the dining area. The area is mostly public space from the living room to the dining area which does not provide privacy between host and guest. The living room was used by the host and guest as an area for relaxing and socializing. At the dining area, there was a toilet that usually used by the host and family members. The dining area is slightly cluttered which indirectly it can be considered as not Shari'ah compliant as cleanliness is very important in the Islamic way of life.

\section{Conclusion}

Spatial organization - The host provides two guest rooms so the house can fit more than one group or family. However, only one room provided with bathroom. The second room needs to share a toilet with the host's family. This might cause privacy disturbance between the host and guest. Both rooms 
provide enough utilities for guest's comfort like air conditioner, wardrobe, carpet, table, and necessities for daily prayer. Both rooms are maintained well and in high cleanliness.

Social interaction - The host practices good values among family and guest. The guests are served with good meals. They are invited to eat together with a host family. The guests also at the same time were allowed to freely move around the house but in a good manner like covering the aurah. The host also promotes ukhwah by encouraging the guests to join them in conducting daily activities.

Landscape setting - The surrounding environment of the house is kept in good manner and cleanliness. Several facilities are provided for guest's comfort like covered parking area, covered performance area, mini nursery, outdoor toilet and canopy for cooking. However, the aesthetic value is still low without proper plants selection and design but still serve the function like planting at the house entrance to give a sense of welcoming and planting alongside the water canal for safety.

\section{Acknowledgement}

This work was supported by the Ministry of Higher Education (MOHE) and International Islamic University Malaysia (IIUM) under Research Grant MOHE18-001-0001

\section{Corresponding Author}

Assoc. Prof. Dr. Rashidi Othman

International Institute of Halal Research and Training (INHART),

KAED, International Islamic University Malaysia,

Jalan Gombak, 53100 Kuala Lumpur, Malaysia.

Email: rashidi@iium.edu.my

\section{References}

Boonratana, R. (2010). Community-based Tourism in Thailand: The Need and Justification for an Operational Definition, Kasetsart Journal Social Science, Vol. 31(2): 280-289.

Ibrahim, Y. and Abdul Razzaq, A. R. (2010). Homestay Program and Rural Community Development in Malaysia, Journal of Ritsumeikan Social Sciences and Humanities, Vol.1(7).

Intan, O., Noor Hazlina, A. and Zainal Ariffin, A. (2011). Understanding motivation, empowerment and sustainability outcomes of women Homestay entrepreneurs in West Malaysia: A preliminary analysis, ICSB World Conference Proceeding

Kayat, K. (2007;2009). Customer Orientation Among Rural Homestay Operator in Malaysia, ASEAN Journal on Hospitality and Tourism,6, 65-78.

Levina., Ross, N. and Jeanne, W. (2003), From the Vendor's Perspective: Exploring the Value Proposition in Information Technology Outsourcing, MIS Quarterly Vol.27(3)

Mortada, H. (2003). Traditional Islamic Principle of Built Environment, Routledge Curzon, Taylor and Francis Group, London.

Mousavi, S. S., Dorati, N., Mousavi, S. N. and Moradiahari, F. (2016). Defining CulturalTourism, International Conference on Civil, Architecture and Sustainable Development.

Michal, S., Lucyna, P. and Frank, S. (2009), Agritourism, AMA DataSet Ltd, UK

Nawawi, I., (2013), The Complete Forty Hadith (3rd edition), Ta-Ha Publishers Ltd, London, UK Othman, R., Saffinee, S. S., Has-Yun Hashim, K. S., Baharudin, Z. M., Mahamod, L. H. and Ibrahim, M. 
(2015). Shariah Compliant Audit Checklist Accommodation Premises, Advanced Science Letters, 21(6), 1721-1724

Omer, S. (2013), Studies in The Islamic Built Environment, IIUM Press, International Islamic University Malaysia.

Pusiran, A. K. and Xiao, H. (2013). Challenges and Community Development: A Case Study of Homestay in Malaysia, Asian Social Science, Vol. 9(5).

Rashidi, O., Hanie, M. L., Saufi, M. D., Zubaidah, A. K., Zainul, M. B., and Syakirin, H.H, (2015), Muslim-Friendly's Homestay in Malaysia: Issues and Challenges, Advanced Science Letters, 21(6), 1655-1657.

Siwar, C. (2013), The Role of Homestays in Community-Based Tourism Development in Malaysia, presented at Conference on Innovating Community Based Tourism (CBT) IN ASEAN, Bangkok.

Yusof, Y., Muda, M. S., Amin, W. A. and Yahaya, I. (2013). Rural Tourism in Malaysia: A Homestay Program, China-USA Business Review, 12(3), 300-306. 